\title{
Retraction Note: Time exposure acoustics in seismic exploration
}

I. Aigbedion and O. Egwebe

Published online: March 2015

(C) 2015 The Editorial Department of APPLIED GEOPHYSICS

\section{Retraction to: Applied Geophysics (2006) \\ 3(3), 148-155 \\ DOI 10.1007/s11770-006-0022-3}

This article has been retracted at the request of The Editorial Office of Applied Geophysics as it involves plagiarism. It has $47 \%$ similarity index with a published article: S. J. Norton, Time exposure acoustics, Geoscience and Remote Sensing, IEEE Transactions, 2000, 38(3), 1337-1343, DOI: $10.1109 / 36.843027$ 